\title{
A Study of English Writing Center in Canadian Higher Education and Its Implications on College English Writing Teaching
}

\author{
Shunling Wang \\ School of Foreign Languages \\ University of Jinan \\ Jinan, Shandong, China
}

\begin{abstract}
College English writing, as one of the important means of acquiring knowledge and communicating ideas, is the necessary learning skill in the college study. The English writing center in Canada has been flourishing in the recent years and has become one of the key parts in writing instruction systems and higher education of Canada. This paper gave an insight into Canadian English writing center, including its development, the current situation and its future in the new century. Also, some implications enlightened by Canadian writing centers concerning Chinese writing teaching and relieving writing fossilization are analyzed. Hopefully some references might be made for college English writing teaching and writing studies in China.
\end{abstract}

Keywords-Canada; Writing Center; English writing instruction; writing fossilization

\section{INTRODUCTION}

Writing is undoubtedly the necessary skill in the process of education at all levels. In China, writing teaching is far from satisfying in college English teaching, since students have many difficulties in the practical writing (Cai Huiping, Fang Yan, 2006). In CET Band 4 and 6, college students' writing score hovers around 6 to 7 points, which means that the average score of college students is actually below the passing line (Cai Jigang, 2002). Namely, their writing proficiency is not satisfying. It is found that many learners couldn't make any progress in spite of their efforts and their writing is seemingly stable, even a majority of students' English writing are fossilized(Wang Shunling, 2008). From the point of teaching, some external objective factors are the leading factors to their writing fossilization, especially the current college English writing instruction cannot meet the writing needs of learners. How to improve college English writing teaching, relieve college English writing fossilization, and constantly enhance the learner's writing proficiency has been the focus in the writing research. The writing center, a new way of writing instruction, has become an important part of the international writing research focus. Canadian

Fund Project:

1. Shandong Social Science Project : "Research on College English Writing Fossilization in Second Language Acquisition" (No: 14CWXJ41);

2. The Key Teaching Research Project of University of Jinan "Research on the elimination of College English Writing Fossilization" (No JZ1318). university writing center is growing rapidly in many colleges and universities all over the country. Canada's writing instruction is diversified due to the various characteristics of history, culture and education, etc. Writing center as one of diversified education systems is an important content and an important part of higher education (Graves, 1983). As a visiting scholar funded by China Scholarship Council in 2015 , the author made a detailed study of Canadian writing center, including the development history, present situation and development trend etc, in order to introduce a better writing instruction to improve college English writing teaching in China and help to eliminate writing fossilization, and provide a reference for writing research as well.

\section{WRITING CENTER}

\section{A. The Development of Writing Center}

Writing center originates from North America in the 1960 s and 1970s. It is a center of the "consciousness", helping learners to locate the causes of writing difficulties and provide guidance (North, 1994:12). With the combination with " process-oriented writing " and "studentcentered" writing theories, the writing center provides writing instructions not only to help learners write a piece of good article, but also cultivate excellent writers (North, 1984:442). Established in 1983, International Writing Center Association ( IWCA) has been promoting the development of the Writing Center all over the world. At present, the writing center are widely set up and flouring in many colleges and universities of Asia, Africa, Europe, the United States, etc.

Canadian writing center was firstly set up at University of Toronto and York University in the 1960s. In 1964, Professor King and Cotter at Innis college founded the first writing learning lab (Innis Writing Lab), creating a new model of writing instruction beyond classroom teaching to provide learners "one-to-one" or individual instruction. They believe that the personalized guidance can promote learners' writing thinking and consciousness in the process of writing learning, (King \& Cotter, 1970). In 1967, The center for academic writing at university of York was set up to provide personalized academic writing tutoring to solve writing 
problems to help students become independent writers (Sheese, 2006). At the very beginning, the writing center was considered simply a fix-it shop or writing clinic to help students modify language, grammar and punctuation, etc. (Yahner \& Murdick, 1991), which is regarded as secondary teaching units in colleges and universities without standing academic status (Procter, 2011). After decades of unremitting efforts, writing center has not only gained widespread recognition as the teaching, administrative and academic unit at college and universities, but also hailed as the teaching base for developing students' intelligence and academic capacity (Graves, 2006). In recent years, with the promotion of Canadian Writing Center Association (CWCA), writing center of Canadian higher education attaching great importance to the writing process, has made consistent development to satisfy learners' writing needs. Also, except the "one-to-one" tutoring, the writing center has developed some diversified instruction methods, such as workshops and online tutoring, etc. Writing center is currently the core of culture life in Canadian colleges and universities (Graves, 2006) in the whole process of college students' learning. To set up a writing center to help learners construct knowledge structure and cultivate learners' writing ability has become one of the teaching tasks of colleges and universities (Procter, 2006).

\section{B. The Present Situation of Writing Center in Canada}

The education report released by the Canadian federal government in the 1990s made clear that one of the future education goals is to improve the basic learning skills including reading, writing and so on, and make efforts to establish lifelong learning system, mentoring, and internet counseling system. In order to develop learners' basic skills of writing, the vast majority of colleges and universities have set up writing center to cultivate outstanding writers and improve students' writing skills. According to the writing center list directory in 2014 posted on the official website of CWCA (the three special administrative region are excluded), the general statistics of Canadian university writing centers in different provinces are made by the author. The statistics results indicate that the Canadian university writing center has been developing rapidly in recent years, with a total of 103 writing centers set up in 73 colleges and universities separately in 10 provinces of Canada. In details, nearly half of writing centers are set up in the province of Ontario, covering the majority of Canadian writing centers; Other provinces in line with the total number of writing centers in turn are: British Columbia, Alberta, Nunavut, Saskatchewan, Manitoba, Quebec, Newfoundland and Labrador and Prince Edward island. Obviously, Canadian colleges and universities collectively have paid close attention to the cultivation of students' writing skills, generally a writing center set up in each university at least, or even more than one writing centers in a single university. For example, over 15 writing centers are set up in university of Toronto (Procter, 2006), five writing center are set up at university of Regina of Saskatchewan and its federated colleges, and four writing centers are set up in university of Ottawa, Ontario. In a word, it's obvious that universities and colleges in Canada have attached great importance to the construction and development of writing center to cultivate excellent writers be the means of extracurricular tutoring.

The tutoring staff in writing center are mainly fulltime or part-time teachers, and a few graduates with advanced writing proficiency serving as "big students, little head" (Mick, 1999:33-50). The guiding principle of the writing center is to create relaxing and lively atmosphere of counseling, encouraging students to actively participate in the writing center; based on the writing requirement, the students' writing process is the focus, helping analyze the causes of writing difficulties to encourage learners to constantly refine the written passage by themselves, instead of just working as "super proofreader" to help them proofread or correct language mistakes (North, 1994:11).

Students can drop in or book time online (North, 1984:12) to take the "face-to-face or one-to-one" personalized writing instruction. The writing guidance is flexible, varying from person to person, in which tutors and learners may talk about the writing problems face to face in various ways, such as: questions, praise, comparison, etc.. Particularly, common knowledge in writing are introduced and discussed in details to help understand and familiarize with all the writing process. For example, some writing strategies to build writing knowledge structure can be described and some methods and measures could be generalized to interfere with various writing problems. Besides "one-to-one" personal guidance, free writing workshop on different writing topics involving the different stages of the writing processes and group instruction providing students with group counseling could help learners better understand the standards and requirements of all levels of academic writing. In addition, online writing tutoring on the particular website of writing center could help learners acquire writing knowledge in their convenient time.

\section{Major Contributions of Canadian Writing Center}

The widely recognized writing center has made remarkable contributions to the development of college writing teaching practice to meet the different requirements of students' diversified writing learning background.

1) It is a new type of writing education: The writing center is the supplement and reinforcement of the classroom teaching, which is "revolutionary" in the writing education system (North, 1984: 18). Also, combined with other professional and academic disciplines, the writing center actively also uses effective resources, such as WAD (writing-across-discipline) or academic writing courses to widen writing center instructions.

2) The unique style is worth learning and promoting: Based on "process-oriented writing" and "the studentcentered" writing theory, writing center is dedicated to cultivating outstanding writers with independent thought. The diversified writing instruction of writing center, such as "one-to-one" personalized writing instruction, kinds of writing seminars or workshops and online tutoring, actively intervene students' writing problems, help them establish the correct thinking mode of writing process and constantly 
promote the improvement of writing level. Therefore, it is worth learning and promoting in English writing education.

3) The writing center opens up a new field of academic research: The various regional organizations and academic journals published about writing center on promoting the theory and practice of writing center has played a positive role in the study of writing center. With Canadian Writing Center Association as an example, the annually held meeting has been providing management and services for the Canadian University Writing Center, supporting the concerned research and development, promoting the academic and teaching exchanges, enhancing the development of the cause of Canadian writing center. At present, the research focus of writing center is how to create and develop writing center, how to carry out academic researches, second language writing research and related research on writing tutor. In addition, with the development of theoretical and empirical studies related to the writing center, it is found out that the research on the Canadian writing center has become an important part in the international writing academic research.

Although the establishment of the writing center has played an active role in promoting the teaching and researches of writing, it still needs to be improved in the aspects of work feedback, system and team building. For example, the writing center has not yet regulated a stable model for employment management (Procter, 2011). In all, these factors have a negative impact on the development of writing center.

\section{THE DEVELOPMENT TREND OF THE CANADIAN UNIVERSITY WRITING CENTER}

It is predicted that Canadian writing center will be the future trend and the original form of the professional writing department in Canada(Graves, 2006), which will play a leading role in writing education (Procter, 2011). The establishment, the development of tutoring methods and the changes in the mode of work and other aspects of the future development of the writing center will be discussed here.

\section{A. The Multi-functional and All Levels of the Writing Center Will Be Widely Established}

In order to meet the diverse writing needs of students, the independent college writing center tend to integrated with other disciplines and ESL/EFL. Effective writing should be closely related to the discipline-specific (Evans, 2003), namely the general knowledge and skills of writing, and the learners' personal major are needed in the writing as well. With the professional requirements for writing, the writing center need to jointly build multifunctional writing centers with many departments, the discipline construction and development, such as: library, school of education and other related institute, WAD writing center in order to meet the writing requirements of different learners. With the increasing number of international students in Canada, the special need for ESL/EFL is on the rise. The establishment of ESL/EFL writing center can help second language learners to obtain more guidance, and promote the acquisition and development of writing skills. Professor Moussu, chairman of CIWA, explores the necessity of ESL/EFL writing center (Moussu, 2013), calling for more ESL writing experts to provide guidance in ESL/EFL Writing Center. It can be seen that a single tutor in writing center can't meet the diversified need of any student of different majors.

\section{B. Online Tutoring Will Be the Future Trend}

It should be said that the trend of the interactive online tutoring tend to be the most convenient form for students in the global world. Online tutoring can not only solve the problem of the site and equipment cost of the writing center, but also the payment of the tutors and the manager will be greatly reduced. Online writing tutorings exemplified as the online conversation tools or a video conference software is helpful for tutors to listen to, understand and make timely response to the writing problems of students. (Neaderhiser \& Wolfe, 2009). With the development of science and technology, the twenty-first century will meet the online tutoring writing center widely and quickly(Kinkead, 2000).

\section{The Working Mode of the Writing Center Tends to Be Diversified}

Besides the face-to-face and online tutoring, all kinds of seminars or workshops are very suitable to help students better understand and solve the writing problems. The principles of writing center are unified, but the diversified working mode could be adopted flexibly to meet the needs of different learners (Wolcott, 1987).

\section{THE IMPLICATION ON THE WRITING TEACHING IN CHINA}

It is clear that Canadian writing center is an good example to promote the teaching of College English writing in China, which is conducive to the improvement of English learners' writing proficiency and elimination of the writing fossilization of College students.

\section{A. To Implement the "Students-centered" Teaching Idea}

Canadian writing centers center around the specific needs of writing learners with the purpose of cultivating excellent writers, which is a typical and effective example to understand the learners' main difficulties, problems, specific requirements in English writing, to implement the "studentcentered" writing teaching concept, improve the practical teaching of English writing, promote learners' writing proficiency, and gradually eliminate the writing fossilization.

\section{B. To Attach Importance to Process-oriented Writing Idea}

Writing is an important process of knowledge exchange and expression of ideas. Traditional English writing teaching pays more attention to the mode of training (Ye Hong, 2012), which often ignores the teaching of writing process. Being lack of proper guidance is one of the objective factors which lead to college English writing fossilization. The process of writing is essential in the writing teaching. Therefore, 
Canadian university writing center is significant and worthwhile to be studied, optimizing the process of writing teaching, supplementing the teaching mode and teaching methods to intervene and weaken the writing fossilization.

\section{To Try to Promote the Establishment of College English Writing Center}

With the fast development of colleges and universities writing center in Canada, only a few writing centers have been set up in China, which can't match the present situation of English writing teaching and the big population of ESL learners. Therefore, to attempt to practice operating the teaching mode of writing center in English writing teaching in Chinese universities is much rewarding. Learning from the tutoring mode of Canadian writing center, some qualified universities might try to set up a pilot English Writing Center in the faculty or school units to offer writing guidance outside the classroom, thus creating more external environment and diversified guidance to help college English learners constantly improve writing skills and eliminate writing fossilization.

\section{To Develop Diverse Forms of Writing Instruction}

At present, the writing course is merely a part of reading and writing course, colleges and universities in China have no independent college English writing course except for some elective writing courses. This kind of single writing instruction can not meet the writing learning requirements for learners of different writing levels. The diversified work modes of writing center, such as one-to-one personalized tutoring, writing seminars or workshops and online tutoring forms, can provide the useful reference for the single writing education system in our country and enrich the domestic writing education as well.

\section{CONCLUSION}

It is clear that the education concept and diverse flexible instruction methods of Canadian writing centers should be actively concerned, and it is of great significance to be a good example to enrich our instruction method and writing researches in China and relieving writing fossilization. In the study of English writing, it is greatly necessary for us to keep abreast of new progress in the study of the writing center abroad, to be closely connected with international writing research, to strengthen the research on the theory and practice of writing, expand the writing research field on fossilization, and to promote domestic college English writing theory and practice research. The topic of writing center is a new research field and it is expected that the experts in the field of domestic English writing can further the research of writing center deeply.

\section{REFERENCES}

[1] Cai Jigang, 2002, Influence of CET Writing Requirements and Scoring Criteria [J]. Journal of PLA University of Foreign Languages, (5): $49-52$.
[2] Cai Huiping, Fang Yan, The Survey and Analysis on Problems Exiting in English Writing[J]. Foreign Languages and Foreign Language Teaching, 2006, (9): 21-25.

[3] Evans, K. 2003. Problems in the Writing Center [J]. Academic Exchange Quarterly, 7 (4), 261-268.

[4] Graves, R. 1983. Composition in Canadian Universities [J].Written Communication, 10 (1), 73-104.

[5] Graves, R. \& Graves, H. 2006. Writing Centers, Writing Seminars, Writing Culture: Wring Instruction in Anglo-Canadian Universities [C]. Winnipeg: Inkshed Publications, 1-21.

[6] Kinkead, J. \& Harris, J. 2000.What's Next for Writing Centers? [J]. The Writing Center Journal, 20 (2), 23-24.

[7] King, D. \& Cotter, E. 1970. An Experiment in Writing Instruction [J]. English Quarterly, 3 (2), 48-56.

[8] [8]Mick. C. S. 1999. "Little Teachers," Big Students: Graduate Students as Tutors and the Future of Writing Center Theory [9]. The Writing Center Journal, 20 (1), 33-50.

[9] Moussu, L. 2013. Let's talk! ESL Students' needs and Writing Center Philosophy [J]. TESL Canada Journal, 30 (2), 55-68.

[10] Neaderhiser, S. \& Wolfe, J. 2009. Between Technological Endorsement and Resistance: The State of Online Writing Centers [J]. The Writing Center Journal, 29 (1), 49-77.

[11] North, S. M. 1984. The Idea of a Writing Center [J]. College English, $46(5), 433-446$.

[12] North, S. M. 1994. Revising "The Idea of a Writing Center" [J]. The Writing Center Journal, 15 (1), 7-19.

[13] Procter, M. 2006. "The University of Toronto: Catching Up to Ourselves". in Graves, R. \& Graves, H. Writing Centers, Writing Seminars, Writing Culture: Wring Instruction in Anglo-Canadian Universities [C]. Winnipeg: Inkshed Publications, 297-316.

[14] Procter, M. 2011. "Talking the Talk and Walking the Walk: Establishing the Academic Role of Writing Centres". in Writing in Knowledge Societies [C]. Fort Collins, Colorado: The WAC Clearinghouse and Parlor Press, 415-439.

[15] Sheese, R. et al. 2006. "Faculty of Arts Center for Academic Writing: York University, Toronto". in Graves, R. \& Graves, H. Writing Centers, Writing Seminars, Writing Culture: Wring Instruction in Anglo-Canadian Universities [C]. Winnipeg: Inkshed Publications, 255-272.

[16] Wang Shunling, 2008, Research on Fossilization in College English Writing[J]. Foreign Language in China, 5 (6): 68-73.

[17] Wolcott, W. 1987. Establishing Writing Center Workshops [J]. The Writing Center Journal, 7 (2), 45-49.

[18] Yahner, W. \& Murdick, W. 1991. The Evolution of a Writing Center: 1972-1990 [J]. The Writing Center Journal, 11 (2), 13-28.

[19] Ye Hong, 2012, Critical Pedagogy in Chinese EFL Writing Programs [J]. Foreign Langue Research, (4):118-122.

[20] Zhou Mansheng, 1993, The Problems of Canada and the Development Goals in This Century [J]. Studies In Foreign Education, (3):18-19. 